\title{
Engineering Properties and Mineralogical Identification of Soil from Melange in Sandakan Sabah, Malaysia
}

\author{
Baba Musta
}

\begin{abstract}
A total of five soil samples were collected from melange weathered material in order to analysis the engineering properties and mineralogical identification of the soils. The soil samples were collected along the main road in Sandakan, Sabah. The result of analysis shows that the soil moisture content was in the range of $15.26 \%$ to $22.10 \%$, the soil organic content range from $1.10 \%$ to $2.32 \%$, and the soil specific gravity in the range of 2.57 to 2.61. Sample S3 and S4 shows the acidity of soil whereas, S1, S2 and S5 was alkaline. The average liquid limit of soil samples were from $45.1 \%$ to $59.8 \%$, while the plasticity indexes were in the range of $23.25 \%$ to $33.91 \%$. The plasticity chart plot of soil found that $\mathrm{S1}$ and $\mathrm{S} 5$ samples were classified as low plasticity soil, while $S 2, S 3$ and $S 4$ samples were classified as high plasticity. The result shows that the optimum moisture contents range from $13.0 \%$ to $28.9 \%$, while the maximum dry density was within a range from $1.43 \mathrm{Mg} / \mathrm{m}^{3}$ to $1.82 \mathrm{Mg} / \mathrm{m}^{3}$. The unconfined compression strength indicated that $\mathrm{S3}$ is classified as very soft soil, S1 and S4 soft soil, S2 moderate soft soil and s5 strong soil. The permeability of all soil samples is best classified as very low permeability. The mineralogical identification using XRD and SEM proved the appearance of clay minerals and quartz as a main mineral content of all soil samples.
\end{abstract}

Keywords - soil, melange, engineering properties, mineralogy

\section{Introduction}

The study area is located in the main road of Sandakan, Sabah, Malaysia which often occurrences of landslides and soil creep that cause road damaged. The soil mostly originated from weathered mélange materials. The melange consists of mixed rocks including blocks of different ages and origin, commonly embedded in shale matrix (1). The admixture of rocks with varies sizes and varied with matrix of sandstone, mudstone shale and clay in Sandakan area was reported as

Baba Musta, Afrida Abd Karim, Hennie F. W. S. Erfen

Programme of Geology

Science and Technology Complex

Faculty of Science and Natural Resources

Universiti Malaysia Sabah

88400, Kota Kinabalu, Sabah, Malaysia

Kyoung Woong Kim \& Joon Ha Kim

International Environmental Research Center

Gwangju Institute of Science and Technology,

123 Cheomdan-gwagiro, Buk-gu, Gwangju, Korea

Garinono Formation or Broken Formation (2) and (3).
According to (4) mélange has lack of internal continuity of rock layer and contact, therefore this structure contributed to the damage of rock structure. Different soil has different strength, depending on its parent material and mineral contents. Friction strength of soil influenced by its mineral contents, shape of soil particles, pore ratio, organic materials content and soil grades (5). Besides of geological factors, this study area has tropical climate which experience high rainfall intensity throughout the year. Fine grain soil became low plasticity and slurry when mixed with high percentages of water therefore will trigger the landslide (6) and (7). Plasticity nature of clay makes it susceptible to failure due to reduce of soil shear strength. This situation is probably due to the rock and soil type in this area which consists of clayey soils. Most landslides are triggered by hydro climatic events such as prolonged or intensive rain (8) and (9). Understanding the engineering properties and main type of minerals is vital in order to understand the relationship with the occurrences of landslide in this area.

\section{Material and Methodology}

Field investigations involved the study of mélange distribution, slope along the main road and sample collection. About five soil samples were collected from the slopes along the main road in the study area. Study of slope distribution and parameters includes the record of slope orientation, angle, length, height, and the type and extent of vegetation of the area. The occurrence of groundwater seepage on the area is also recorded.

The laboratory analysis involved the physico-chemical analysis, engineering properties analysis, and mineral content analysis. The parameters in physico-chemical analysis are natural moisture content, organic content, $\mathrm{pH}$ value, particle size distributions and specific gravity of soil. The physicochemical analysis were followed BS1377 methods (10). The Atterberg's limits were analyzed to identify the type of soil plasticity. Engineering properties consist of Proctor test, and unconfined compression test (UCT) and permeability test. The microstructures of the soil sample were observed using SEM analysis and the identification of soil minerals were analyzed using XRD. The identification of minerals from X-Ray Diffractograms was based on Moore and Reynolds (11). 
Proc. of the Fourth International Conference on Advances in Civil, Structural and Environmental Engineering - ACSEE 2016. Copyright ( $)$ Institute of Research Engineers and Doctors. All rights reserved.

ISBN: 978-1-63248-114-6 doi: 10.15224/ 978-1-63248-114-6-32

\section{Result and Discussions}

\section{A. Physico-chemical properties}

Table 1 shows the results of analysis for moisture content, organic matter content, specific gravity, and $\mathrm{pH}$ for five soil samples collected from mélange materials in Sandakan, Sabah. Base on the table the soil moisture content was at the range of $15.26 \%$ to $22.10 \%$; the soil organic content range from $1.10 \%$ to $2.32 \%$; the soil specific gravity at the range of 2.57 to 2.61 , and the average $\mathrm{pH}$ value was from $\mathrm{pH} 4.80$ to $\mathrm{pH} 7.60$. Sample S3 and S4 shows the acidity of soil whereas, S1, S2 and S5 was alkaline. Sample S3 shows the highest moisture content which was $22.10 \%$, while S4 shows the highest soil organic content $(2.32 \%)$ and highest specific gravity (2.61). The specific gravity tests were conducted to determine the density of each soil sample by calculating the ratio between the mass of dry soil and distilled water.

TABLE I. PHYSICO-CHEMICAL PROPERTIES OF SOILS

\begin{tabular}{|c|c|c|c|c|}
\hline $\begin{array}{c}\text { No. } \\
\text { Sample }\end{array}$ & $\begin{array}{c}\text { Moisture } \\
\text { content } \\
\text { Wo (\%) }\end{array}$ & $\begin{array}{c}\text { Soil } \\
\text { organic } \\
\text { matter } \\
\text { content. } \\
\text { OM (\%) }\end{array}$ & pH & $\begin{array}{c}\text { Specific } \\
\text { Gravity } \\
\text { SG }\end{array}$ \\
\hline S1 & 16.05 & 1.11 & 7.45 & 2.60 \\
\hline S2 & 20.75 & 1.32 & 7.60 & 2.58 \\
\hline S3 & 22.10 & 2.12 & 5.25 & 2.57 \\
\hline S4 & 16.00 & 2.32 & 4.80 & 2.61 \\
\hline S5 & 15.26 & 1.10 & 7.51 & 2.58 \\
\hline
\end{tabular}

Table II shows the percentage of clay, silt and sand for all five soil samples. . Based on the Head (12) classification, it was found that all soil samples were best classified as clay soil. The uniformity coefficient $(\mathrm{Cu})$ and curvature coefficient $(\mathrm{Cc})$ results indicated the $\mathrm{S} 1$ was uniform and well graded; while the rest were poorly graded.

TABLE II. GRAIN SIZE DISTRIBUTIONS OF SOILS

\begin{tabular}{|c|c|c|c|c|c|}
\hline \multirow{2}{*}{ Sample } & \multicolumn{3}{|c|}{ Percentages of Grain size (\%) } & \multirow{2}{*}{$\begin{array}{l}\text { Soil } \\
\text { Classi- } \\
\text { fication }\end{array}$} & \multirow[b]{2}{*}{ Grade } \\
\hline & Clay & Silt & Sand & & \\
\hline S1 & 34.58 & 41.59 & 23.83 & Clay & Well sorted \\
\hline S2 & 40.49 & 44.25 & 15.26 & Clay & Poorly sorted \\
\hline S3 & 36.83 & 33.63 & 29.54 & Clay & Poorly sorted \\
\hline S4 & 41.60 & 34.00 & 24.40 & Clay & Poorly sorted \\
\hline S5 & 34.91 & 49.83 & 15.26 & Clay & Poorly sorted \\
\hline
\end{tabular}

The result of Atterberg's limits tests for five soil samples are given in Table III. Atterberg's limits consist of plastic limit test, liquid limit test, soil plasticity index and linear shrinkage. Soil conditions can be divided into four phases, namely solid, semi-solid, plastic and liquid (12).

TABLE III. RESULTS OF THE ATTERBERG'S LIMIT

\begin{tabular}{|l|l|l|l|l|} 
Sample & Average & Average & Plasticity & Linear \\
\hline
\end{tabular}

\begin{tabular}{|c|c|c|c|c|}
\hline & $\begin{array}{c}\text { liquid } \\
\text { limit, } \mathbf{L}_{\mathbf{L}} \\
(\boldsymbol{\%})\end{array}$ & $\begin{array}{c}\text { plastic } \\
\text { limit, } \mathbf{P}_{\mathbf{L}} \\
(\boldsymbol{\%})\end{array}$ & $\begin{array}{c}\text { index, } \mathbf{I}_{\mathbf{P}} \\
(\boldsymbol{\%})\end{array}$ & $\begin{array}{c}\text { shrinkage, } \\
\mathbf{L}_{\mathbf{S}} \\
(\boldsymbol{\%})\end{array}$ \\
\hline S1 & 45.1 & 21.85 & 23.25 & 12.14 \\
\hline S2 & 56.4 & 22.49 & 33.91 & 13.57 \\
\hline S3 & 59.8 & 33.49 & 26.31 & 17.14 \\
\hline S4 & 56.2 & 27.84 & 28.36 & 15.00 \\
\hline S5 & 46.4 & 21.48 & 24.92 & 12.86 \\
\hline
\end{tabular}

Based on the analysis, average liquid limit of soil samples were from $45.1 \%$ to $59.8 \%$. Average plastic limit ranged from $21.48 \%$ to $33.49 \%$, while the plasticity indexes were in the range of $23.25 \%$ to $33.91 \%$. The plasticity chart plot of soil found that S1 and S5 were classified as low plasticity soil, while S2, S3 and S4 soil were classified as high plasticity (Figure 1). Based on the clay activity analysis it was found that all soil samples are classified as inactive clay except for S2 soil which classified as normal clay. The analysis results showed the linear shrinkage percentage was at the range of $12.14 \%$ to $17.14 \%$.

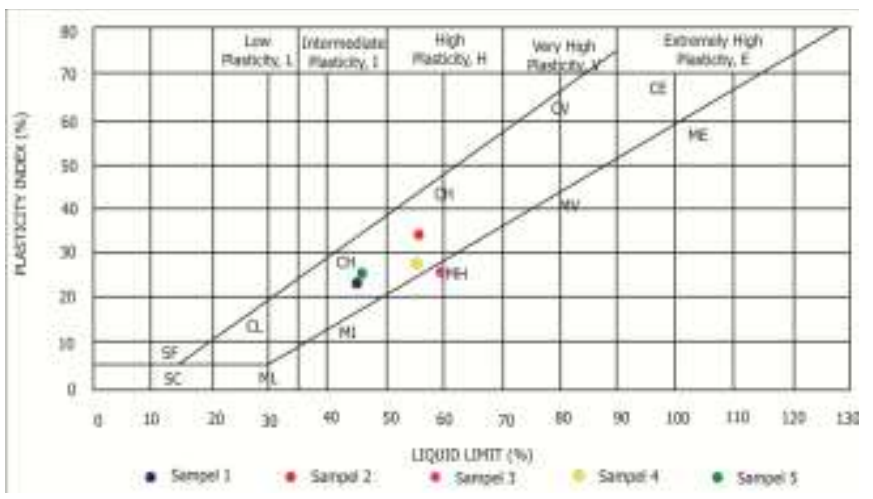

Figure 1. Plasticity chart of soil samples.

\section{B. Engineering properties}

The engineering properties consist of compaction test, unconfined compression test, and permeability test. Proctor compaction test were conducted to determine the maximum dry density and optimum moisture content of the soil samples. This test is intended to increase the density of the soil samples by reducing the volume of the air space between the soil particles through compaction methods. Table IV shows the optimum optimum soil moisture content, maximum dry density. The result shows that the optimum moisture contents ranged from $13.0 \%$ to $28.9 \%$, while the maximum dry density is within a range from $1.43 \mathrm{Mg} / \mathrm{m}^{3}$ to $1.82 \mathrm{Mg} / \mathrm{m}^{3}$. 
Proc. of the Fourth International Conference on Advances in Civil, Structural and Environmental Engineering - ACSEE 2016. Copyright $(\odot$ Institute of Research Engineers and Doctors. All rights reserved.

ISBN: 978-1-63248-114-6 doi: 10.15224/ 978-1-63248-114-6-32

\begin{tabular}{|c|c|c|c|c|}
\hline & $\begin{array}{c}\text { Moisture } \\
\text { content, } \\
\text { Wopt } \omega_{\text {o }} \\
(\%)\end{array}$ & $\begin{array}{c}\text { Dry } \\
\text { density, } \\
\mathbf{p}_{\mathbf{D}}\left(\mathbf{M g} / \mathbf{m}^{\mathbf{3}}\right)\end{array}$ & $\begin{array}{c}\text { compression } \\
\text { test } \\
\mathbf{( k P a )}\end{array}$ & $\begin{array}{c}\text { bility } \\
\text { value, } \\
\mathbf{k}(\mathbf{m} / \mathbf{s})\end{array}$ \\
\hline S1 & 14.0 & 1.82 & 56.70 & $5.12 \times 10^{-8}$ \\
\hline S2 & 14.0 & 1.76 & 124.3 & $3.09 \times 10^{-9}$ \\
\hline S3 & 28.5 & 1.43 & 16.87 & $2.66 \times 10^{-8}$ \\
\hline S4 & 25.5 & 1.51 & 54.08 & $2.02 \times 10^{-9}$ \\
\hline S5 & 13.0 & 1.78 & 203.57 & $1.03 \times 10^{-8}$ \\
\hline
\end{tabular}

Unconfined compression test was conducted to determine the stress strength of the soil samples when subjected to compressive forces. Stress resistance strength is the maximum power per soil area that can be produced by a soil sample to prevent failure or slide along its plane. The unconfined compressive strength classifications were based on Terzaghi et. al (13) classification. The result of the unconfined compression test shows that S3 is classified as very soft soil, S1 and S4 soft soil, S2 moderate soft soil and S5 strong soil (Table IV). The permeability tests were conducted to determine the permeability of the soil to drain water between its pore spaces. The result shows that the permeability of all soil samples is best classified as very low permeability (13).

\section{Mineralogical Study}

Analysis of mineral content in the soil samples was based on X-ray diffraction (XRD) analysis and scanning electron microscope (SEM). The result of XRD analysis shows that the main mineral content in the soil samples are quartz $(\mathrm{Q})$, kaolinite (K) and ilite (I). The micro morphology and micro structure of soil from SEM images show the appearance of kaolinite layered, while illite which has a finer grain size than kaolinite also were observed. The X-ray diffractograms and electron microscopic images for samples S1, S2, S3, S4 and $\mathrm{S} 5$ are given in Figure 1, Figure 2, Figure 3, Figure 4 and Figure 5 respectively.

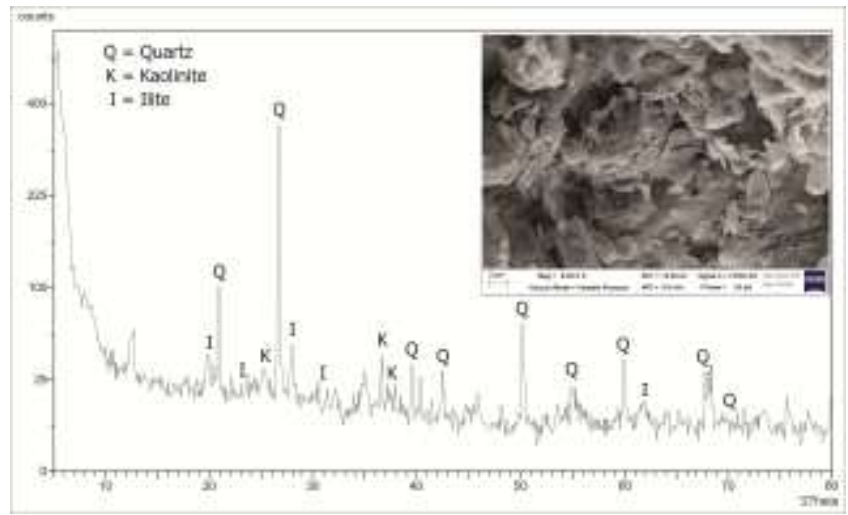

Figure 1. X-ray diffractograms and electron microscope image for S1.

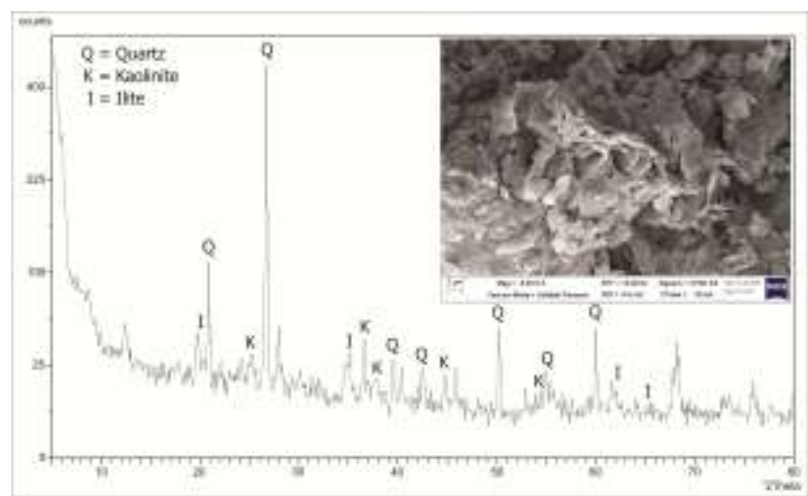

Figure 2. X-ray diffractograms and electron microscope image for S2.

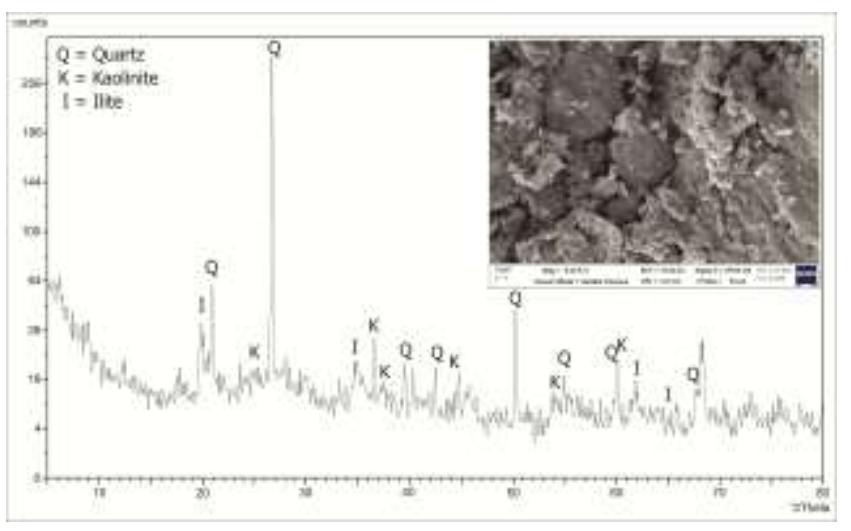

Figure 3. X-ray diffractograms and electron microscope image for S3.

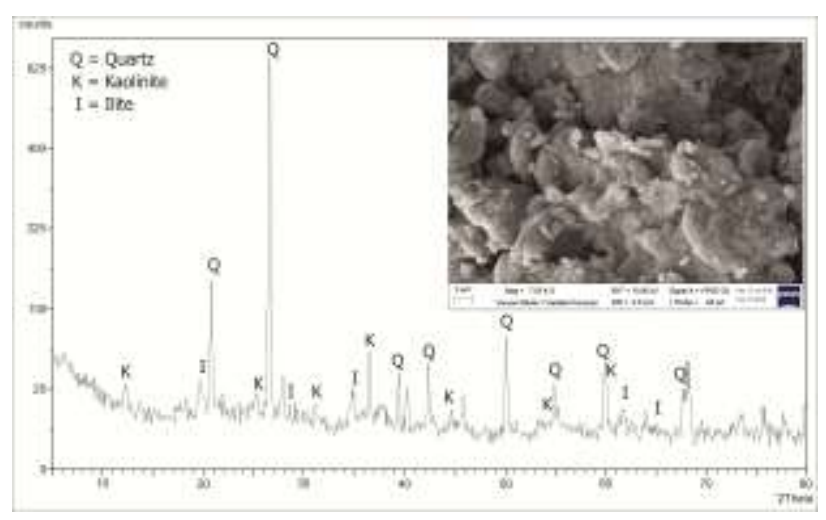

Figure 4. X-ray diffractograms and electron microscope image for S4. 
Proc. of the Fourth International Conference on Advances in Civil, Structural and Environmental Engineering - ACSEE 2016. Copyright ( $)$ Institute of Research Engineers and Doctors. All rights reserved.

ISBN: 978-1-63248-114-6 doi: 10.15224/ 978-1-63248-114-6-32

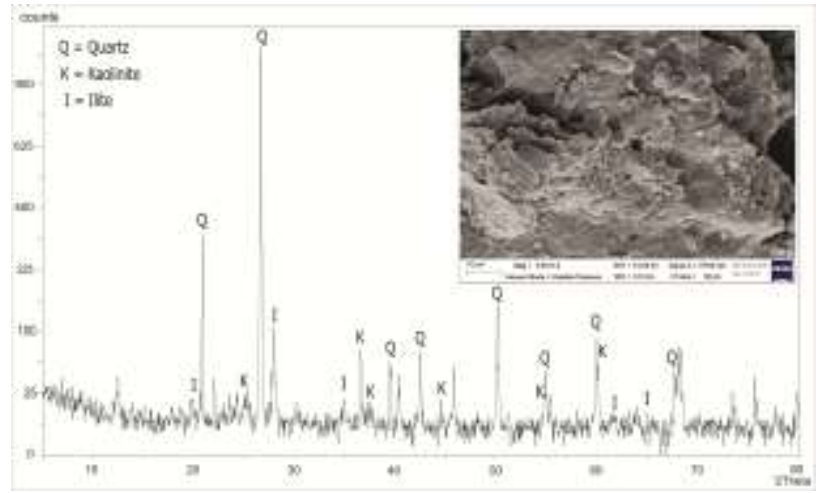

Figure 5. X-ray diffractograms and electron microscope image for S5

\section{Conclusions}

i. The soil samples from mélange shows that the moisture content, organic matter and specific gravity were $15.26 \%$ $22.10 \% ; 1.10 \%-2.32 \%$; and $2.57-2.61$ respectively. The $\mathrm{pH}$ value was varies from acidic (4.80) to alkaline (7.60). The average liquid limit was $45.1 \%-59.8 \%$, while the plasticity index was $23.25 \%$ to $33.91 \%$. The plasticity chart of soil shows that S1 and S5 were classified as low plasticity soil, while S2, S3 and S4 soil were classified as high plasticity.

ii. The result of engineering properties shows that the optimum moisture contents ranged from $13.0 \%$ to $28.9 \%$, while the maximum dry density is within a range from $1.43 \mathrm{Mg} / \mathrm{m}^{3}$ to $1.82 \mathrm{Mg} / \mathrm{m}^{3}$. The unconfined compression strength indicated that S3 is classified as very soft soil, S1 and S4 is soft soil, S2 is moderate soft soil and s5 is strong soil. The permeability of all soil samples is classified as very low permeability.

iii. The mineralogical identification using XRD and SEM proved the appearance of main mineral content of all soil is kaolinite, illite and quartz.

\section{Acknowledgment}

This study was supported by the Ministry of Science and Technology in South Korea through the Institute of Science and Technology for Sustainability (UNU\& GIST Joint Programme) in 2016. All laboratory works have been done in the Faculty of Science and Natural Resources, Universiti Malaysia Sabah, Kota Kinabalu, Sabah, Malaysia.

\section{References}

[1] Sanudin, Tahir \& Baba Musta. Pengenalan Kepada Stratigrafi (Introduction to Stratighraphy). Universiti Malaysia Sabah, Kota Kinabalu, 2007

[2] P. Collenette. The Garinono Formation, Sabah, Malaysia. Borneo Region, Malaysian Geological Survey Annual Report for 1966, 161-167

[3] C. S. Hutchison. Geology of North-West Borneo Sarawak, Brunei and Sabah.Elsevier B.V. Netherlands. 2005.

[4] A. Festa. G. A. Pini, Y. Dilek, G. Codegone,. \& A. Camerlenghi. Melange Types and Tectonic Setting of Their Formation, EGU General
Assembly 2010, p. $6671 . \quad$ http://dx.doi.org/10.1080/ $\underline{002068109035557704}$

[5] M. D. Braja. Fundamentals of Geotechnical Engineering $4^{\text {th }}$ Ed. Cengage Learning. 2012

[6] M. K. Hossain. Effect of Rainfall on Matric Suction and Stability of a Residual Granite Soil Slope. Dhaka University of Engineering \& Technology Journal ; 2010. Vol 1, 37-41.

[7] M.A. J. Jeans \& E. Tommy. Effects of External Water-Level Fluctuations on Slope Stability. EJGE : Electronic Journal of Geotechnical Engineering ; 2014, Vol 19, 2437-2463.

[8] M. Jacob. \& S. Lambert, 2009. Climate Change Effect on Landslide Along the Southwest Coast of British Columbia. Canada.

[9] S. Syaran, A. Fauziah. A.Y. Ahmad, A. M. Zul, H.. H. Climate Change Impact on Water Level in Peninsular Malaysia. Journal of Civil Engineering Research 2014, 4(3A), 228-232.

[10] British Standards 1377:1990. Methods of Test for Soils for Civil Engineering Purpose. British Standard Institution, London.

[11] D. M. Moore \& R. C. Reynolds. X-Ray Diffraction and the Identification and Analysis of Clay Minerals $2^{\text {nd }} E d$. Oxford University Press. Oxford. 1997

[12] K. H. Head. Manual of Soil Laboratory Testing $3^{\text {rd }}$ Edition. Whittles Publishing. 2008

[13] K. Terzaghi, R. B. Peck \& G. Mesri. Soil Mechnics in Engineering Practice $3^{\text {rd }}$ Ed. Wiley-Interscience. 1996

About Main Author:
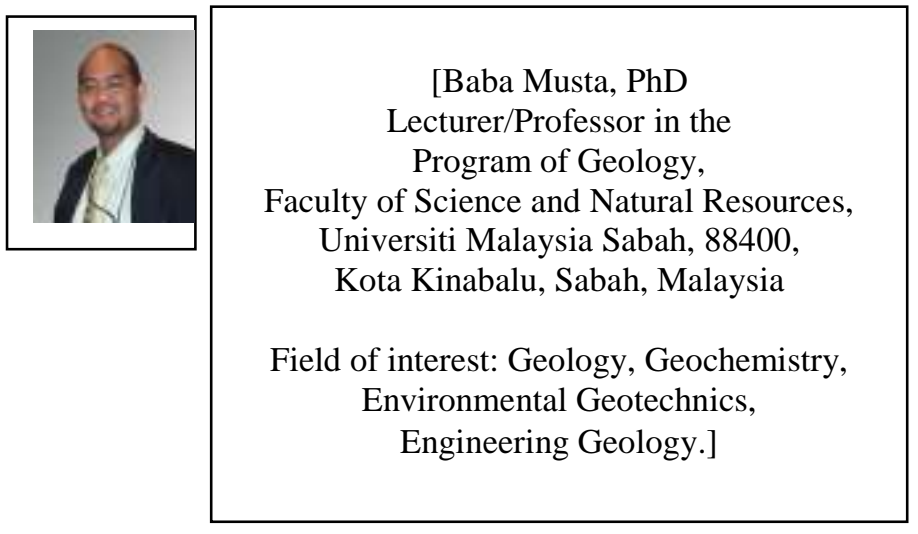